\title{
Comparison of Recent and Former Satellite-Based Gravity Models: A Case Study of Kansas, USA
}

\author{
Yeni ve Eski Uydu Tabanlı Gravite Modellerinin \\ Karşıllaştırılıması: Kansas, ABD Örnek Çalışma
}

Fikret Doğru1*,

\author{
${ }^{1}$ Ataturk University, Oltu Vocational College, Construction Technology, 25400, Erzurum, TURKEY \\ Corresponding Author : fikretjfm@gmail.com \\ Geliș Tarihi / Received: 04.10.2020 \\ Araștirma Makalesi/Research Article \\ Kabul Tarihi / Accepted: 25.01.2021 \\ DOI:10.21205/deufmd.2021236911 \\ Atıf sekli/How to cite: DOGRU F.(2021). Comparison of Recent and Former Satellite-Based Gravity Models: A Case Study of Kansas, USA. \\ DEUFMD 23(69), 835-844.
}

\section{Abstract}

Satellite-based gravity models have been used constantly in many different areas recently. The easy accessibility of the data provides great advantages for difficult conditions such as mountainous areas or the ability to calculate directly for inaccessible areas such as Arctic regions. In addition, shallow studies are possible by increasing the spatial resolution over time by using new satellites and new models obtained from these satellite data. Spatial resolution can be increased with the use of terrestrial data and thus the most representative satellite gravity model which has the lowest error may be determined for a region. It is thought that the results obtained from the studies with this lowest error model represent that region in the best way. Within the scope of this study, experiments were conducted for former and current satellite gravity models using terrestrial gravity data that was collected in Kansas state. Besides, comparisons were made at different degree/order using only GOCE satellite gravity models (long wavelengths) and combined models (short wavelengths). As $8.63 \mathrm{mGal}$ lowest error between satellite models and terrestrial data was obtained from XGM2019e_2159 and ERTM2160 combination. In the comparison between GOCE models, GOCE TIM R5 model gave the lowest error with a difference of $9.94 \mathrm{mGal}$. Although it is observed that the difference between the other combined models and the results obtained from the XGM2019e_2159 model does not exceed $0.4 \mathrm{mGal}$ for degree up to 2190 and these values are not considered as a big difference in geophysical studies, but the sensitivity of these values is much more important in geodetic studies.

Keywords: Kansas, GOCE, XGM2019e_2159, gravity, satellite, terrestrial

Özet

Uydu tabanlı gravite modelleri son zamanlarda pek çok farklı alanda kullanılmaktadır. Verilere kolay erișilebilirlik, dağllk alanlar gibi zor koșullar için veya Arktik bölgeleri gibi erișilemeyen alanlar için doğrudan hesaplama imkanı büyük avantajlar sağlamaktadır. Ayrıca yeni uydular ve bu uydu verilerinden elde edilen yeni modeller sayesinde zaman içinde uzaysal çözünürlük artırılarak sığ çalışmalar yapmak mümkün olacaktır. Karasal verilerin kullanılmasıyla uzaysal çözünürlük artırllabilir ve böylelikle bir bölge için en düşük hataya sahip o bölgeyi temsil eden uydu gravite modeli belirlenebilmektedir. Bu en düșük hata modeli ile yapılan çalıșmalardan elde edilen sonuçların o bölgeyi en iyi şekilde temsil ettiği düşünülmektedir. Bu çalışma kapsamında, Kansas eyaletinde toplanan karasal gravite verileri kullanılarak eski ve güncel uydu yerçekimi modelleri için denemeler yapılmıștır. Ayrıca, sadece GOCE uydu gravite modelleri (uzun dalga boyları) ve kombine modeller (kısa dalga boyları) kullanılarak farklı derece ve sırada karșılaștırmalar yapılmıștır. Uydu modelleri ve karasal veriler arasındaki en düșük hata 8,63 mGal olarak 
XGM2019e_2159 ve ERTM2160 kombinasyonundan elde edilmiștir. GOCE modelleri arasındaki karşılaştırmada, GOCE TIM R5 modeli 9,94 mGal farkla en düşük hatayı vermiştir. Diğer birleşik modeller ile XGM2019e_2159 modelinden elde edilen sonuçlar arasındaki farkın 2190'a kadar olan derece için 0,4 mGal'ı geçmediği ve bu değerler jeofizik çalışmalar için önemli olmadığı halde jeodezik çalıșmalar için önemlidir.

Anahtar Kelimeler: Kansas, GOCE, XGM2019e_2159, gravite, uydu, karasal

\section{Introduction}

Satellite-based gravity models are used in many areas such as crustal modelling [1], [2], [3], [4], [5], [6], [7], determination of faults and discontinuities [8], [9], geoid determination [10], [11] etc.. Besides, the assessment of satellite-based gravity models is substantial for precise studies [7], [12], [13], [14], [15].

Important structural features of the Kansas city are given in Figure 1. These are Cherokee basin, Dodge City basin, Forest City basin, North Kansas basin, Salina basin, Central Kansas Uplift, Nemaha Ridge, Bourbon Arch and Voshell Anticline. The northern part of the Cherokee basin is separated from the Forest City Basin by the Bourbon Arch, and the western side is bounded by the Nemaha Ridge. Dodge City basin is also known as Hugoton Embayment which is the largest structural feature in the southwestern part of Kansas. Forest City basin is bounded on the west by Nemaha Ridge, on the southwest by Bourbon Arch. Nemaha Ridge is buried Precambrian uplift that is bounded by several high angle reverse and normal faults and the rock type is characterized by mostly granitic rocks [16]. Salina basin is bounded on the east by North Kansas Basin, on the west by Central Kansas Uplift [17], [18].

In this study, a statistical study was carried out by comparing the terrestrial gravity data collected in Kansas state of the USA with the global gravity anomalies obtained from former and new satellite gravity models. The topography of the region decreases from west to east (Figure 1). Both the Gravity Field and Steady-State Ocean Circulation Explorer (GOCE) based satellite gravity model data and combined models such as Earth Gravitational Model 2008 (EGM2008), EIGEN-6C4,

GECO, XGM2019e_2159 have been tried. In addition, the terrain correction of the region was performed with the ERTM2160 model [19]. As a result of terrain correction, the difference between terrestrial data and XGM2019e_2159 model was obtained the lowest value as 8.63 mGal.

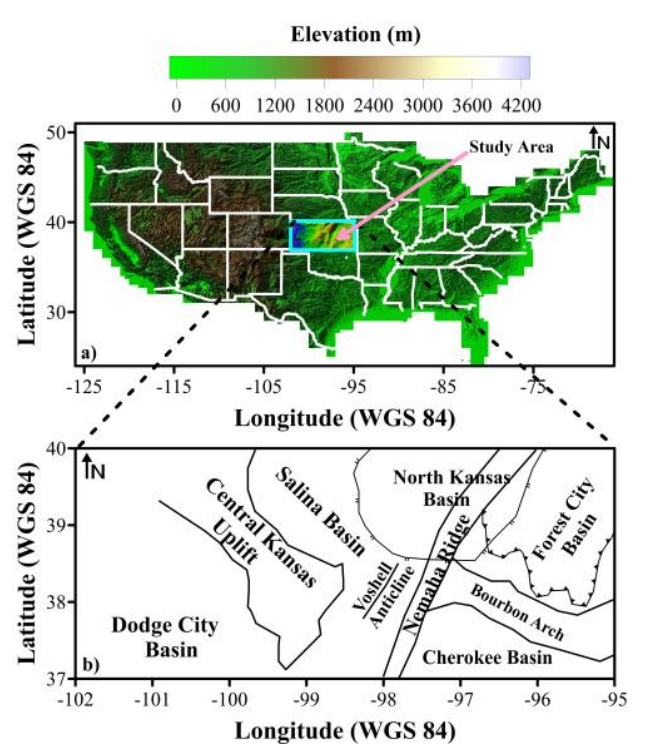

Figure 1. a) Topography map of the United States of America and location map of the study area (white lines indicate city borders and Cygan rectangle shows the study area borders) and b) Major structural features of Kansas (modified from [20]).

\section{Material and Method}

\subsection{Global Gravity Models (GGMs)}

Within the scope of this study, recent and former GGMs such as Earth Gravitational Model 2008, EIGEN-6C4, GECO and XGM2019e_2159 were used to compare at same degree and order (d/o: 2190/2159). Earth Gravitational Model 2008 (EGM2008), which is obtained by the combination of Laser Geometric Environmental Observation Survey (LAGEOS) and Gravity Recovery and Climate Experiment (GRACE) satellite, has been publicly released by the U.S. National Geospatial-Intelligence Agency (NGA) EGM Development Team. This gravitational model is complete to spherical harmonic degree and order 2159 and contains additional coefficients extending to degree 2190 and order 2159 [21]. EIGEN-6C4 is a static global combined gravity field model up to degree and 
order 2190 and it has been released by the collaboration of GFZ Potsdam and GRGS Toulouse. EIGEN-6C4 model was obtained by the combination of LAGEOS degree 2 to 30 (1985-2010), GRACE RL03 GRGS ten years (2003-2013) and the Gravity Field and SteadyState Ocean Circulation Explorer (GOCE) SGG data [22]. GECO is a global gravity model which is computed by combining the GOCE-only TIM R5 solution into EGM2008 [23]. XGM2019e combined global gravity field model from the Technical University of Munich is available in three different expansions. The coefficients are precalculated in the spheroidal harmonic domain and then converted into spherical harmonics and available as "XGM2019e" up to spherical harmonic d/o 5540, "XGM2019e_2159" to 2190 and "XGM2019" up to d/o 760 [24]. EGM2008, EIGEN-6c4, GECO and XGM2019e_2159 GGMs were calculated up to degree 2190 to compare both models at the same degree.

Furthermore, mentioned GGMs were compared with GOCE based GGMs up to degree 240. For this purpose, GO_CONS_GCF_2_TIM_R6(GOCE_TIM_R6), GO_CONS_GCF_2_DIR_R6 GO_CONS_GCF_2_TIM_R5(GOCE_TIM_R5), GO_CONS_GCF_2_DIR_R5 (GOCE_DIR_R5), GO_CONS_GCF_2_TIM_R4(GOCE_TIM_R4), GO_CONS_GCF_2_DIR_R4 (GOCE_DIR_R4) GOCE based models were used and the used models were presented in Table 1.

\subsection{Terrestrial Data}

Gravity survey of Kansas was completed by the Kansas Geological Survey (KGS) and 31.000 gravity points were collected using LaCoste \& Romberg model G and D meters and Worden gravimeter [25]. Bouguer gravity anomaly map was digitized and compared with the GGMs. Bouguer anomaly values vary between $-143-6$ mGal (Figure 2). Topographic elevations, which are gathered from Earth Explorer (USGS) portal as Shuttle Radar Topography Mission (SRTM) 1 arc second resolution, change between 200 to $1200 \mathrm{~m}$ and elevation values increase from East to West so thus Bouguer anomaly values decrease from East to West (Figure 3). Mean of Bouguer anomaly is $-73.5 \mathrm{mGal}$ and standard deviation of Bouguer anomaly is $26.1 \mathrm{mGal}$.

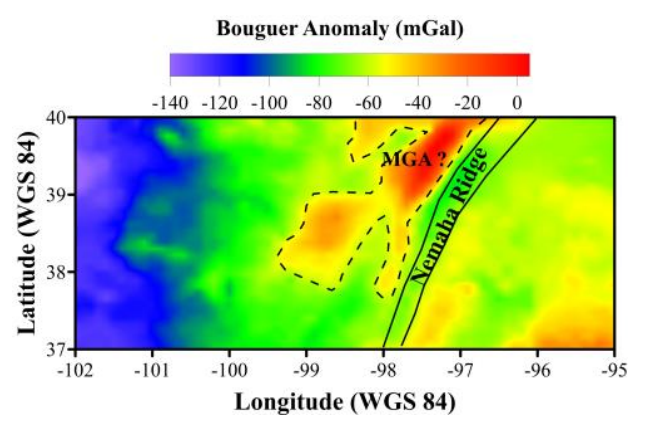

Figure 2. Bouguer gravity anomaly of Kansas (digitized from [25]) (MGA: Midcontinent Geophysical Anomaly).

The positive anomaly at Midcontinent Geophysical Anomaly (MGA) is thought to be caused by dense basaltic intrusions [26], [27]. It is suggested that the negative anomalies on the west and east side of MGA caused by the continental clastic rocks [18].

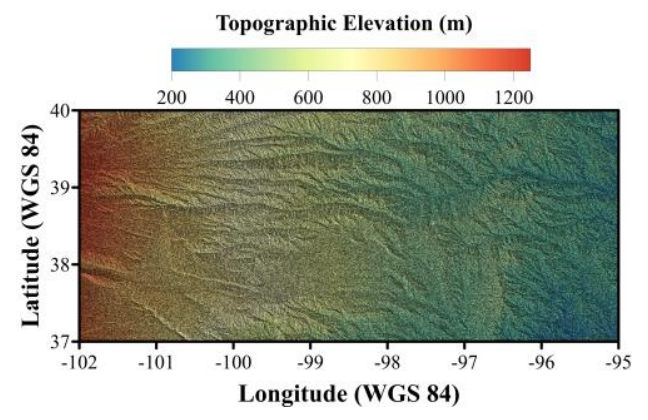

Figure 3. The topographic elevation map of the study area (Elevation data was taken from https://topex.ucsd.edu/cgi-bin/get_data.cgi).

\subsection{Spherical Bouguer Gravity Anomaly Calculation}

In this study, spherical free-air gravity anomalies were calculated using the following equation:

$$
\begin{aligned}
\Delta g_{s a}(r, \varphi, \lambda)=-\frac{\partial T(r, \varphi, \lambda)}{\partial r}-\frac{2}{r} T(r, \varphi, \lambda) & \\
& =\frac{G M}{r^{2}} \sum_{n=n_{\min }}^{n_{\max }}\left(\frac{R}{r}\right)^{n}(n \\
& -1) \sum_{m=0}^{n}\left(\Delta \bar{C}_{n, m} \cos m \lambda+\Delta \bar{S}_{n, m} \sin m\right. \\
& \lambda) \bar{P}_{n, m}(\sin \varphi) \quad(1)
\end{aligned}
$$


where $r, \varphi$ and $\lambda$ are the spherical radius, latitude and longitude; $n, m$ are spherical harmonic degree and order; $n_{\min }$ and $n_{\max }$ are the minimum and maximum degree of spherical harmonic expansion; $\bar{P}_{n, m}(\sin \varphi)$ is $4 \pi$ fully normalized associated Legendre function of the first kind of degree $\mathrm{n}$ and order $\mathrm{m} ; \bar{C}_{n, m}$ and $\bar{S}_{n, m}$ are $4 \pi$ fully normalized spherical harmonic coefficients of degree $n$ and order $m$ related to global geopotential model; $G M$ is the geocentric gravitational constant times Earth-mass and $R$ the Radius of the reference sphere. In addition, $\Delta \bar{C}_{n, m}$ and $\Delta \bar{S}_{n, m}$ are the differences between the spherical harmonic coefficients of the gravity field model and normal gravity field [28].

Then, Bouguer correction was applied to obtain Bouguer anomaly. EGM2008, EIGEN-6C4, GECO and XGM2019e_2159 models were computed up to degree 2190. Also, ERTM2160 model was computed to fill omission error and the values vary between $\pm 2 \mathrm{mGal}$ (Figure 4). Residual gravity model ERTM2160 contains Earth's short-scale gravity field which computed from the SRTM topography at $250 \mathrm{~m}$ resolution and it is freely available via: http://ddfe.curtin.edu.au/models/ERTM2160/ data/dg/ website [19].

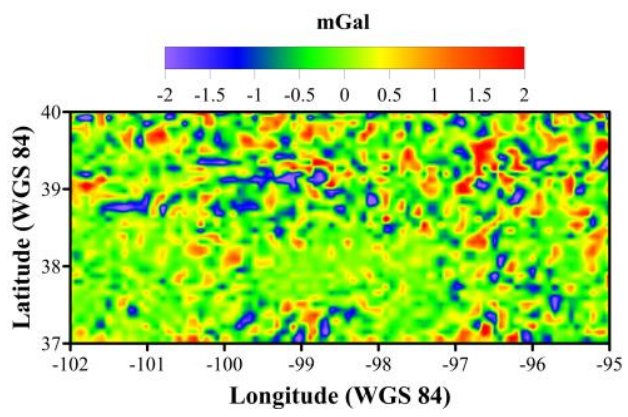

Figure 4. ERTM2160 anomaly map of the study area.

\section{Comparison of GGMs with Terrestrial Data}

In this section, statistical results were obtained using combined models or only GOCE model. First of all, GGMs were calculated up to degree 2190 and the differences between GGMs and terrestrial data were computed and plotted in Figure 5 . The values change between $\sim-60 \mathrm{mGal}$ to $+54 \mathrm{mGal}$. The biggest root mean square (RMS) value was obtained from GECO and terrestrial data difference as $9.23 \mathrm{mGal}$. The differences between EGM2008, EIGEN-6C4 with terrestrial data were obtained the same RMS as $9.11 \mathrm{mGal}$. The lowest RMS and standard deviation (std) values were obtained from the difference of XGM2019e_2159 plus ERTM2160 model and terrestrial data as $8.63 \mathrm{mGal}$ and 8.17 mGal respectively (Table 2). Also, the differences of same models with terrestrial data were computed up to degree 240 using extra only GOCE models. The RMS values of EGM2008, EIGEN-6C4, GECO and XGM2019e_2159 models were obtained almost the same as $\sim 9.73 \mathrm{mGal}$. The lowest RMS value between GOCE models was obtained from GOCE TIM R5 as 9.95 mGal (Table 3). Besides, the differences between GGMs up to degree 2190 were calculated and the lowest RMS was obtained from the differences between GECO and XGM2019e_2159 models as $0.28 \mathrm{mGal}$ in Table 4 (Figure 6).

Finally, the recent model XGM2019e_2159 was used to find out the difference between GOCE models up to degree 240. The highest RMS value was obtained between XGM2019e_2159 and GOCE DIR R4 model as $8.69 \mathrm{mGal}$. Also, the lowest RMS value was obtained from XGM2019e_2159 and GOCE DIR R6 model as $1.62 \mathrm{mGal}$ (Table 5) (Figure 7). 
Table 1. The used GGMs in this study.

\begin{tabular}{ccccc} 
Model & Year & Degree & Data & References \\
\hline EGM2008 & 2008 & 2190 & S (GRACE), G, A & {$[21]$} \\
\hline EIGEN-6C4 & 2014 & 2190 & S (GOCE, GRACE, LAGEOS), & {$[22]$} \\
\hline GECO & 2015 & 2190 & G, A (GOCE), EGM2008 & {$[23]$} \\
\hline XGM2019e_2159 & 2019 & 5540, & A, G, S (GOCO06s), T & {$[24]$} \\
\hline GOCE_TIM_R6 & 2019 & 300 & & {$[30]$} \\
\hline GOCE_DIR_R6 & 2019 & 300 & S (GOCE) & {$[29]$} \\
\hline GOCE_TIM_R5 & 2014 & 280 & S & {$[31]$} \\
\hline GOCE_DIR_R5 & 2014 & 300 & S (GOCE) & {$[32]$} \\
\hline GOCE_TIM_R4 & 2013 & 250 & S (GOCE, GRACE, LAGEOS) \\
\hline GOCE_DIR_R4 & 2013 & 260 & S (GOCE) & {$[31]$}
\end{tabular}
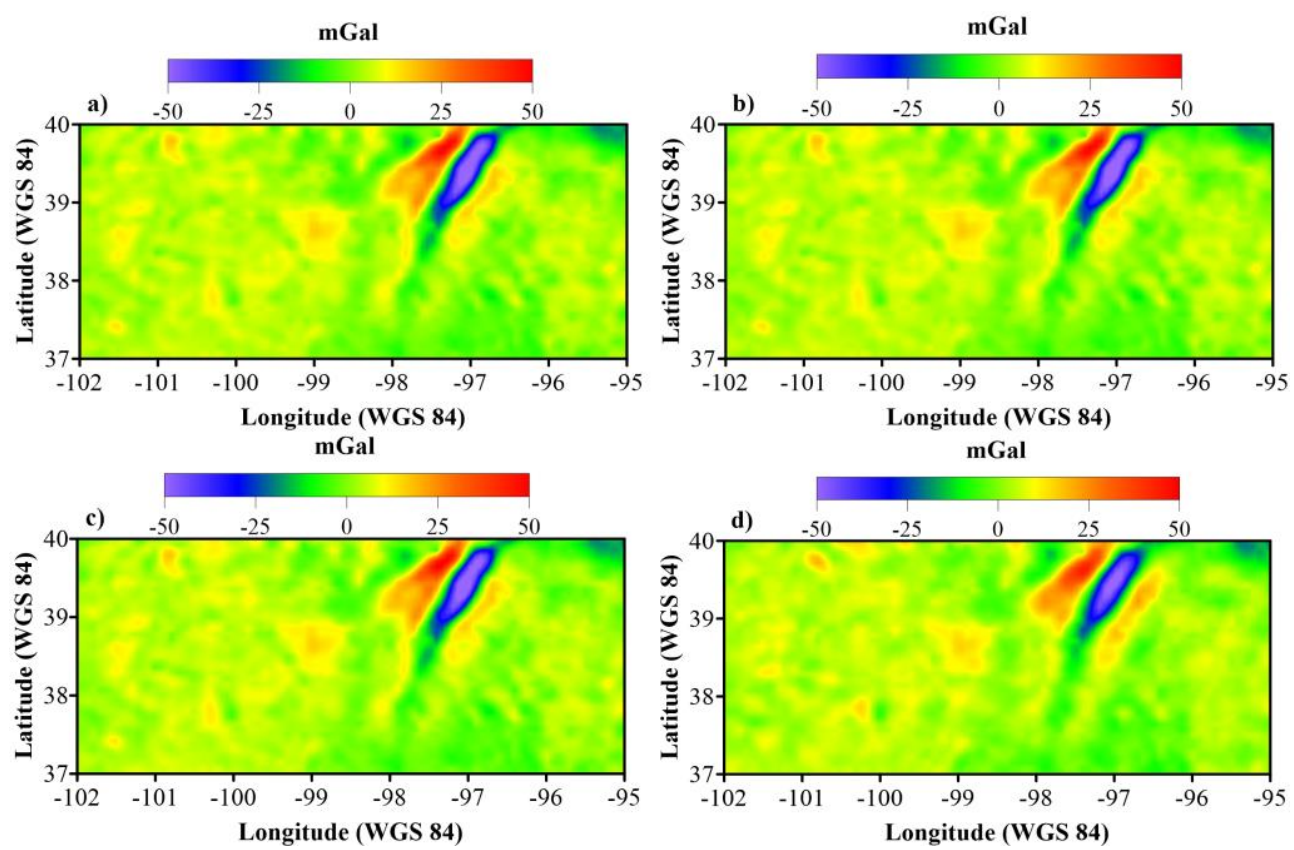

Figure 5. GGMs up to degree 2190 and terrestrial anomaly difference maps: a) Terrestrial minus EGM2008 model, b) Terrestrial minus EIGEN-6C4 model, c) Terrestrial minus GECO model and d) Terrestrial minus XGM2019e_2159. 
DEÜ FMD 23(69), 835-844, 2021

Table 2. The statistics of GGMs and terrestrial anomaly difference.

\begin{tabular}{ccccccc}
\hline & & \multicolumn{5}{c}{ Statistics(mGal) } \\
$\begin{array}{c}\text { Model Name } \\
\text { Maximum Degree }\end{array}$ & Omission Error & Max & Min & Mean & Std & RMS \\
\hline EGM2008 (2190) & - & 51.77 & -57.86 & 2.74 & 8.69 & 9.11 \\
\hline EGM2008 (2190) & ERTM2160 & 52.28 & -58.10 & 2.76 & 8.57 & 9.00 \\
\hline EIGEN-6C4 (2190) & - & 51.6 & -58.43 & 2.75 & 8.69 & 9.11 \\
\hline EIGEN-6C4 (2190) & ERTM2160 & 52.11 & -58.58 & 2.77 & 8.58 & 9.02 \\
\hline $\begin{array}{c}\text { GECO (2190) } \\
\text { GECO (2190) }\end{array}$ & - & 53.32 & -58.46 & 2.74 & 8.81 & 9.23 \\
\hline $\begin{array}{c}\text { XGM2019e_2159 } \\
\mathbf{( 2 1 9 0 )}\end{array}$ & - & 53.82 & -59.25 & 2.76 & 8.7 & 9.13 \\
\hline $\begin{array}{c}\text { XGM2019e_2159 } \\
(2190)\end{array}$ & ERTM2160 & 45.99 & -55.27 & 2.79 & 8.17 & 8.63 \\
\hline
\end{tabular}

Table 3. The statistics of GGMs and terrestrial anomaly difference up to degree 240.

\begin{tabular}{|c|c|c|c|c|c|}
\hline \multirow[b]{2}{*}{$\begin{array}{c}\text { Model Name } \\
\text { Maximum Degree }\end{array}$} & \multicolumn{5}{|c|}{ Statistics(mGal) } \\
\hline & $\operatorname{Max}$ & Min & Mean & Std & RMS \\
\hline EGM2008 (240) & 49.64 & -39.52 & 3.02 & 9.26 & 9.74 \\
\hline EIGEN-6C4 (240) & 49.16 & -40.17 & 3.03 & 9.24 & 9.72 \\
\hline GECO (240) & 49.82 & -39.58 & 3.02 & 9.26 & 9.74 \\
\hline XGM2019e_2159 (240) & 49.65 & -39.48 & 3.02 & 9.25 & 9.73 \\
\hline GOCE DIR R4 (240) & 55.55 & -29.69 & 11.27 & 9.44 & 14.70 \\
\hline GOCE TIM R4 (240) & 48.37 & -38.17 & 2.87 & 9.68 & 10.10 \\
\hline GOCE DIR R5 (240) & 50.27 & -40.49 & 3.03 & 9.53 & 10.00 \\
\hline GOCE TIM R5 (240) & 52.20 & -37.50 & 3.03 & 9.47 & 9.94 \\
\hline GOCE DIR R6 (240) & 51.22 & -38.32 & 3.06 & 9.56 & 10.04 \\
\hline GOCE TIM R6 (240) & 50.89 & -38.19 & 3.05 & 9.57 & 10.04 \\
\hline
\end{tabular}


Table 4. The statistics of GGMs difference up to degree 2190.

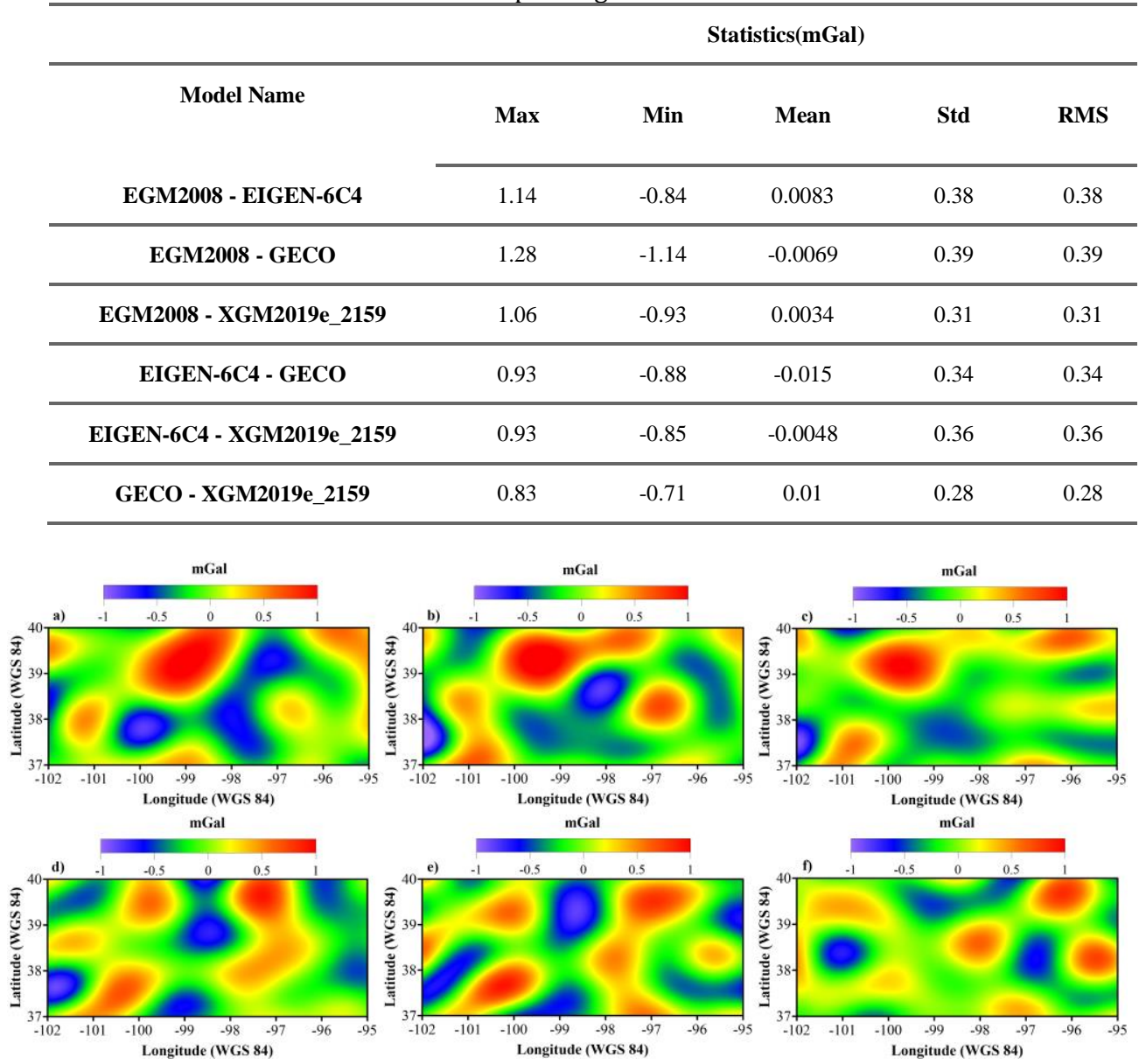

Figure 6. The anomaly maps of GGMs difference up to degree 2190: a) EGM2008 minus EIGEN-6C4, b) EGM2008 minus GECO, c) EGM2008 minus XGM2019e_2159, d) EIGEN-6C4 minus GECO, e) EIGEN-6C4 minus XGM2019e_2159 and f) GECO minus XGM2019e_2159.

Table 5. The statistics of GOCE models and XGM2019e_2159 model difference up to degree 240.

\begin{tabular}{cccccc}
\hline \multirow{2}{*}{ Model Name } & \multicolumn{5}{c}{ Statistics(mGal) } \\
& Max & Min & Mean & Std & RMS \\
\cline { 2 - 6 } XGM2019e_2159 - DIR R4 & 15.9 & 0.07 & 8.2 & 2.87 & 8.69 \\
\hline XGM2019e_2159 - DIR R5 & 5.39 & -5.11 & -0.011 & 1.72 & 1.72 \\
\hline XGM2019e_2159 - DIR R6 & 4.25 & -4.66 & 0.014 & 1.62 & 1.62 \\
\hline XGM2019e_2159 - TIM R4 & 6.94 & -7.93 & -0.18 & 2.84 & 2.85 \\
\hline XGM2019e_2159 - TIM R5 & 5.35 & -4.98 & -0.016 & 2.02 & 2.02 \\
\hline XGM2019e_2159 - TIM R6 & 4.09 & -4.37 & -0.0034 & 1.71 & 1.71 \\
\hline
\end{tabular}



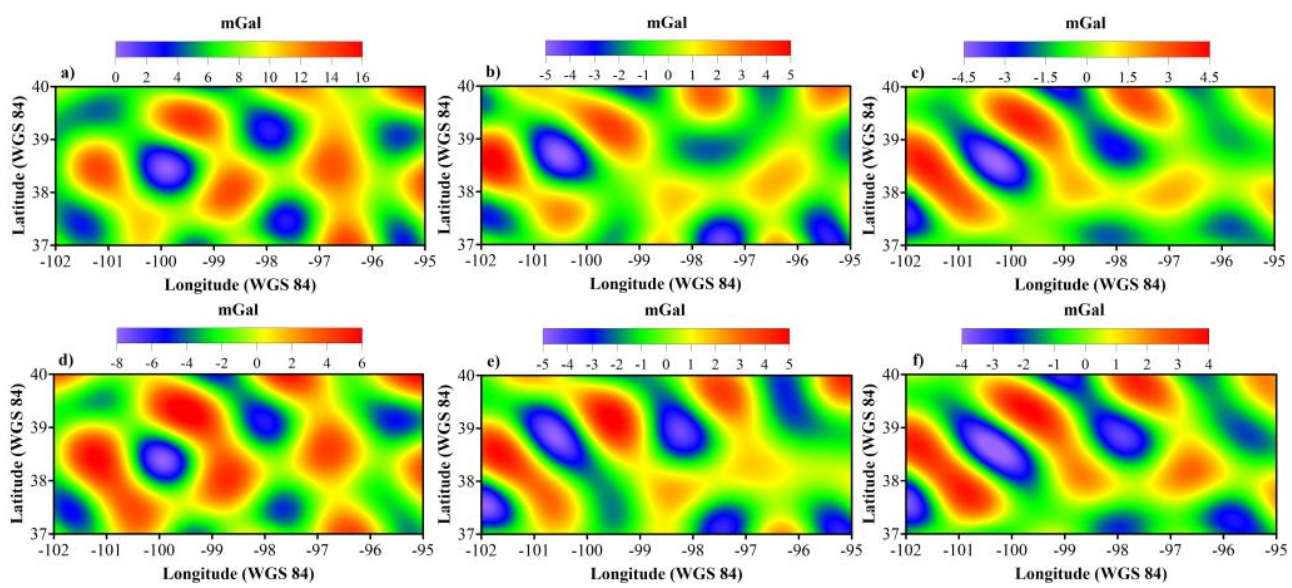

Figure 7. The anomaly maps of GOCE models and XGM2019e_2159 model difference up to degree 240: a) XGM2019e_2159 minus DIR R4, b) XGM2019e_2159 minus DIR R5, c) XGM2019e_2159 minus DIR R6, d) XGM2019e_2159 minus TIM R4, e) XGM2019e_2159 minus TIM R5 and f) XGM2019e_2159 minus TIM R6.

\section{Discussion and Conclusion}

With this study, Bouguer gravity anomaly obtained from the terrestrial data collected from Kansas state of the USA and spherical Bouguer anomalies obtained from satellite gravity models were compared. This comparison was made using both GOCE satellite models and all combined models up to degree 240. Also, current and former combined models were compared up to 2190 degree with and without ERTM2160 model. Also, the models were compared among themselves and statistical results were obtained.

Bouguer gravity anomaly of the region decreases from east to west due to topography (Figure 2). High difference values were obtained between the gravity data collected from the ground and the anomalies calculated from the satellite in the northeast of the region in which is named as the Midcontinent Geophysical Anomaly (MGA) [33], [34] by previous studies and in the area where the Nemaha Uplift is located. It is thought that insufficient ground data into the satellite models may be cause that big differences over MGA and Nemaha Uplift. The highest RMS value with $9.23 \mathrm{mGal}$ was obtained from the GECO model and the lowest RMS value with $8.63 \mathrm{mGal}$ was obtained from the combination of XGM2019e_2159 and ERTM2160 (Table 2). Also, all models have been calculated up to 240 degrees in order to compare GOCE models. Among the GOCE models, the GOCE DIR R4 gave the highest RMS value as $14.70 \mathrm{mGal}$, while the lowest RMS value is calculated with the GOCE TIM R5 model with 9.94 mGal (Table $3)$. The difference results of ground data and EGM2008, GECO, EIGEN-6C4 and XGM2019e_2159 combined models were obtained similar as $\sim 9.73 \mathrm{mGal}$ up to degree 240. In the comparison of the combined models, the difference between GECO and XGM2019e_2159 model is the lowest value as $0.28 \mathrm{mGal}$ (Table 4). Finally, the differences of GOCE models with the new satellite model were calculated (up to degree: 240). The obtained lowest RMS in the difference results was expected to be with the GOCE TIM R6 and XGM2019e_2159 model because the XGM2019e 2159 the combination of GOC006S (GOCE TIM R6, GRACE, Kinematic Orbits, SLR), DTU13 Altimetry, NGA 16 Land (15'), Topography Gravity and EARTH 2014) model was also included the GOCE TIM R6 data (1.71 mGal) but the GOCE DIR R6 result is 1.62 mGal RMS.

As a conclusion, the lowest RMS value for this region was obtained from the XGM2019e_2159 model as a result of the statistical study for the Kansas region. As a result of comparison with only GOCE models, it is seen that GOCE TIM R5 model has the lowest RMS value than others as $9.94 \mathrm{mGal}$. 


\section{Acknowledgment}

The author would like to thank editor and reviewers for their contributions and suggestions.

\section{References}

[1] Wood, R., Woodward, D. 2002. Sediment thickness and crustal structure of offshore western New Zealand from 3D gravity modelling, New Zealand Journal of Geology and Geophysics, 45(2), 243255.

[2] Ebbing, J., Bouman, J., Fuchs, M., Lieb, V., Haagmans, R., Meekes, J.A.C., Fattah, R.A. 2013. Advancements in satellite gravity gradient data for crustal studies, The Leading Edge, 32(8), 900-906.

[3] Lücke, 0.H. 2014. Moho structure of Central America based on three-dimensional lithospheric density modelling of satellite-derived gravity data, International Journal of Earth Sciences, 103(7), 1733-1745.

[4] Reguzzoni, M., Sampietro, D. 2015. GEMMA: An Earth crustal model based on GOCE satellite data, International Journal of Applied Earth Observation and Geoinformation, 35, 31-43.

[5] Alvarez, O., Gimenez, M.E., Martinez, M.P., Klinger, F.L., Braitenberg, C. 2015. New insights into the Andean crustal structure between 32 and $34 \mathrm{~S}$ from GOCE satellite gravity data and EGM2008 model, Geological Society, London, Special Publications, 399(1), 183-202.

[6] Sampietro, D. 2016. Crustal modelling and Moho estimation with GOCE gravity data, In Remote Sensing Advances for Earth System Science, 127 144.

[7] Dogru, F., Pamukcu, O., Gonenc, T., Yildiz, H. 2018. Lithospheric structure of western Anatolia and the Aegean Sea using GOCE-based gravity field models, Bollettino di Geofisica Teorica ed Applicata, 59(2), 135-160.

[8] Mehrnia, S.R., Khaleghi, R. 2014. Determination of Seismic Lineaments by EGM2008 Data and Gravitational Facies in North of Qazvin, Iran, Journal of Seismology and Earthquake Engineering, 16(3), 147.

[9] Doğru, F., Pamukçu, 0. 2019. Analysis of gravity disturbance for boundary structures in the Aegean Sea and Western Anatolia, Geofizika, 36(1), 53-76.

[10] Featherstone, W.E. 2002. Expected contributions of dedicated satellite gravity field missions to regional geoid determination with some examples from Australia, Journal of Geospatial Engineering, 4(1), 1-20.

[11] Garcia, R.V. 2002. Local geoid determination from GRACE mission, Ph.D. thesis, Ohio State University, Division of Geodetic Science, USA.

[12] Bouman, J. 2000. Quality assessment of satellitebased global gravity field models, Netherlands Geodetic Commission. Publications on Geodesy 48, Delft, 1-72.

[13] Pail, R., Plank, G. 2002. Assessment of three numerical solution strategies for gravity field recovery from GOCE satellite gravity gradiometry implemented on a parallel platform, Journal of Geodesy, 76(8), 462-474.
[14] Ray, R.D., Luthcke, S.B. 2006. Tide model errors and GRACE gravimetry: towards a more realistic assessment, Geophysical Journal International, 167(3), 1055-1059.

[15] Farahani, H.H., Ditmar, P., Klees, R. 2014. Assessment of the added value of data from the GOCE satellite mission to time-varying gravity field modelling, Journal of Geodesy, 88(2), 157-178.

[16] Bickford, M.E., Harrower, K.L., Nusbaum, R.L., Thomas, J.J., Nelson, G.E. 1979, Preliminary geologic map of the Precambrian basement rocks of Kansas: Kansas Geological Survey, Map M-9, scale 1:500,000, 1 sheet.

[17] Merriam, D.F. 1963. The geologic history of Kansas. University of Kansas publications.

[18] Steeples, D.W. 1982. Structure of the Salina-Forest City interbasin boundary from seismic studies, In UMR Journal--VH McNutt Colloquium Series, 3, 1, 55-82.

[19] Hirt, C., Kuhn, M., Claessens, S., Pail, R., Seitz, K., Gruber, T. 2014. Study of the Earth's short-scale gravity field using the ERTM2160 gravity model, Computers and Geosciences, 73, 71-80.

[20] Lee, W. 1940. Subsurface Mississippian rocks of Kansas, Kansas Geological Survey Bulletin, 33, 114.

[21] Pavlis, N.K., Holmes, S.A., Kenyon, S.C., Factor, J.K. 2008. An Earth gravitational model to degree 2160: EGM2008, European Geosciences Union General Assembly, 2008, Vienna, Austria.

[22] Förste, C., Bruinsma, S., Abrikosov, O., Flechtner, F., Marty, J.C., Lemoine, J.M., ... and Biancale, R. 2014. EIGEN-6C4-The latest combined global gravity field model including GOCE data up to degree and order 1949 of GFZ Potsdam and GRGS Toulouse, EGU General Assembly Conference Abstracts, 16.

[23] Gilardoni, M., Reguzzoni, M., Sampietro, D. 2016. GECO: a global gravity model by locally combining GOCE data and EGM2008, Studia Geophysica et Geodaetica, 60(2), 228-247.

[24] Zingerle, P., Pail, R., Gruber, T., Oikonomidou, X. 2020. The combined global gravity field model XGM2019e. Journal of Geodesy, 94(7)

[25] Lam, C.K., Yarger, H.L. 1989. State gravity map of Kansas, Kansas Geological Survey. Bulletin, 226, 185-196.

[26] Hahn, R.K. 1980. Upper mantle velocity structure in eastern Kansas from teleseismic P-wave residuals: M. S. thesis, Department of Geology, University of Kansas, 85.

[27] Yarger, H.L. 1980. Aeromagnetic analysis of the Keweenawan rift in Kansas, EOS, American Geophysical Union, Transactions, 61, 48, 1,192.

[28] Bucha, B., Janák, J. 2013. A MATLAB-based graphical user interface program for computing functionals of the geopotential up to ultra-high degrees and orders, Computers and Geosciences, 56, 186-196.

[29] Brockmann, J.M., Zehentner, N., Höck, E., Pail, R., Loth, I., Mayer-Gürr, T., Schuh, W.D. 2014. EGM_TIM_RL05: an independent geoid with centimeter accuracy purely based on the GOCE mission, Geophysical Research Letters, 41(22), 8089-8099.

[30] Bruinsma, S.L., Förste, C., Abrikosov, O., Lemoine, J.M., Marty, J.C., Mulet, S., ... and Bonvalot, S. 2014. ESA's satellite only gravity field model via the 
direct approach based on all GOCE data, Geophysical Research Letters, 41(21), 7508-7514.

[31] Bruinsma, S.L., Förste, C., Abrikosov, O., Marty, J. C., Rio, M.H., Mulet, S. and Bonvalot, S. 2013. The new ESA satellite only gravity field model via the direct approach, Geophysical Research Letters, 40(14), 3607-3612.

[32] Pail, R., Bruinsma, S., Migliaccio, F., Förste, C., Goiginger, H., Schuh, W.D., ... and Veicherts, M. 2011. First GOCE gravity field models derived by three different approaches, Journal of Geodesy, 85(11), 819.

[33] Serpa, L., Setzer, T., Farmer, H., Brown, L., Oliver, J., Kaufman, S., ... and Steeples, D.W. 1984. Structure of the southern Keweenawan rift from COCORP surveys across the Midcontinent geophysical anomaly in northeastern Kansas, Tectonics, 3(3), 367-384.

[34] Somanas, C., Knapp, R.W., Yarger, H.L., Steeples, D.W. 1989. Geophysical model of the Midcontinent Geophysical Anomaly in northeastern Kansas, Kansas Geological Survey Bulletin, 226, 215-228. 